\title{
THE EXECUTIVE BUDGET
}

\author{
By C. H. Crennan, \\ Editor in Charge of Volume.
}

"The budget provides a means through which citizens may assure themselves that their effort which has been diverted to community ends is not used for private gain, is not misused nor frittered away, but is applied to the accomplishment of those purposes which the community approves and is made to produce the maximum of results for the effort expended. Thus viewed, the budget is something more than a method of checking or reducing the tax rate, more than any scheme of accountants and efficiency experts. Above and beyond its relation to economy and efficiency in public affairs it may be made one of the most potent instruments of democracy. Given at least manhood suffrage, any government so organized as to produce and carry out a scientific budget system will be susceptible of extensive and intelligent popular control. On the contrary those governments, whatever their other virtues, which fail to provide adequate budget methods, will neither reach the maximum of efficiency nor prove to be altogether responsible to the people."1 Thus did Professor A. R. Hatton set forth the full import of the executive budget as editor of the volume of The Annals on Public Budgets issued in November of 1915.

It is only because so recent an issue of The Annals was devoted entirely to a detailed discussion of the public budget that this fundamental part of any plan for responsible government is not included in the present volume. For the technical details of budgetary procedure and a full appraisal of the importance of the executive budget, reference must be made to the November, 1915 Annals.

1 The Annals of the American Academy of Political and Social Science, November, 1915, p. vii. 